https://doi.org/10.53937/icz10.2021.15

\title{
CASPIOSOMA CASPIUM (KESSLER, 1877) IN THE LOWER DNIESTER RIVER
}

\section{Dumitru Bulat, Denis Bulat, Nicolae Șaptefrați, Marin Usatîi, Nina Fulga, Dadu Ana}

Institute of Zoology, Chisinau, Republic of Moldova

e-mail: bulatdm@yahoo.com

\begin{abstract}
The result of multiannual research that supports the concept of biological progression of Gobiidae family representatives on the territory of the Republic of Moldova in current ecological conditions are revealed in this paper. A new species was found for the Dniester riverbed - Caspiosoma caspium (Kessler, 1877), in the spring of 2021, being captured in number of 16 specimens, this previously being identified only in the Cuciurgan refrigerated lake in 1969, in a single specimen..
\end{abstract}

\section{Introduction}

In the current ecological conditions, unfortunately, we find profound negative changes in the ichthyofauna of natural aquatic ecosystems in the Republic of Moldova. Often create premises for the emergence and proliferation of large species small of marine or deltaic origin which, previously, were missing within the limits of the republic or were considered very rare, against the background of unregulated fishing with selective effect (when large species are extracted, regulating small numbers), rapid climate change and multiple fragmentations of riverbeds by dams [1]. One of these is the caspian goby - Caspiosoma caspium (Kessler, 1877).

Caspian goby is a relict species of Pontic-Caspian origin, protected by law, included in the Red Book of the Republic of Moldova ed. III with endangered species status (EN) [2] and the Red Book of Ukraine [14], protected at European level (LC) [13].

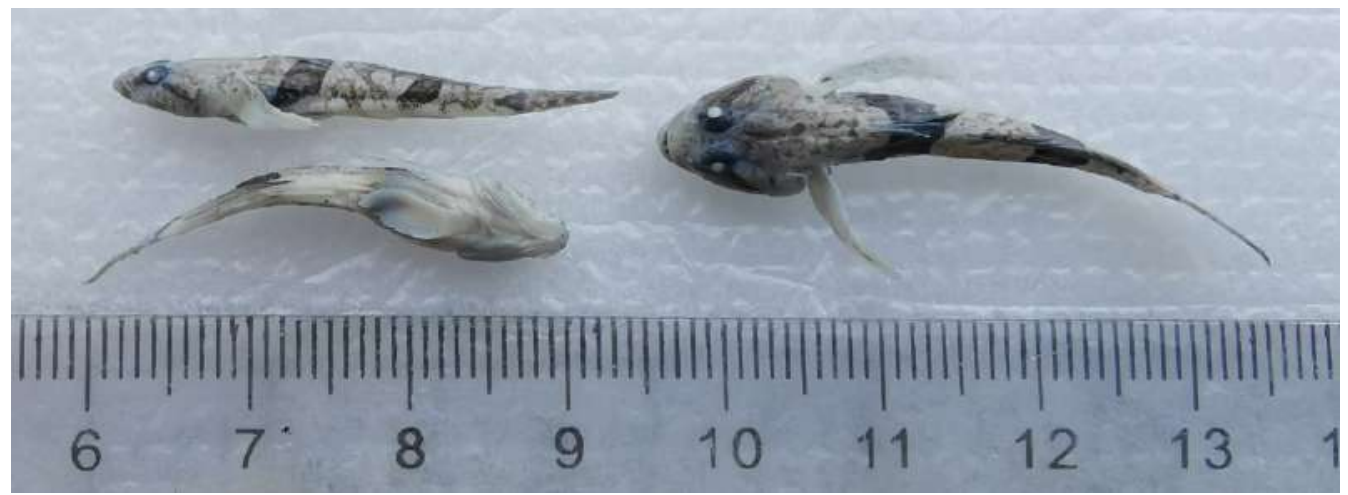

Figure 1. Caspiosoma caspium (Kessler, 1877) - Caspian goby

According to its taxonomic affiliation, it is unique in the Republic of Moldova from the genus Caspiosoma, it belongs to the class Actinopterygii, the order Perciformes, the family Gobiidae.

The species can be found only in the Cuciurgan refrigerated lake, according to some authors 
$[2,3,4,9,12]$. It was identified only once in 1969 in the ecosystem of the Cuciurgan reservoir (Dniester basin), where one specimen only was reported [11].

Abroad it is found in the deltas of rivers flowing into the northwestern part of the Black Sea, the Azov Sea and the Caspian Sea $[6,15,16]$. Also, lately, as a result of the regularization of watercourses, there has been a tendency to expand the upstream distribution area on large rivers. The spread of the species in the Lower Volga River is a typical example. [8].

\section{Materials and methods}

The capture of ichthyological material was carried out in the spring of 2021, in the lower Dniester River, the Purcari-Palanca section. In scientific fishing, the seine net was used with a length of $5 \mathrm{~m}$, height $=2 \mathrm{~m}$, the size of eyes $=10 \times 10 \mathrm{~mm}$, of the bag $=5 \times 5 \mathrm{~mm}$. Classical ecological and ichthyological methods were used to taxonomic determination and analysis of ichthyological material $[6,15]$.

The obtained data were statistically processed using the Excel program - 2007. The values of the analytical and synthetic ecological indices express the following meanings [5]:

$$
\text { D1 subrecedents: }<1,1 \%
$$

D2 recedents: $1,1 \%-2 \%$

C1 accidental: $<25 \%$

D3 subdominants: $2,1 \%-5 \%$

D4 dominants: $5,1 \%-10 \%$

D5 eudominants: $>10 \%$
C2 accessory: $25,1 \%-50 \%$

C3 constants: 50,1\%-75\%

C4 euconstants: $75,1 \%-100 \%$
W1 accidental: $<0,1 \%$

W2-W3 accessory:0,1\%-5\%

W4-W5 characteristic:5,1\%-100\%

*Note: D-dominance, $\mathbf{C}$-constancy, $\mathbf{W}$-ecological significance index

\section{Results and discussions}

According to scientific control fishermen in the spring of 2021 in the Lower Dniester River made by researchers of the Laboratory of Ichthyology and Aquaculture of the Institute of Zoology, have been identified 16 specimens of this species. The captured specimens were processed metrically and gravimetrically, having the following values: $n=16$, L med. $=3,43 \pm 0,16$ $\mathrm{cm}$ (C.V.=18,32\%), 1 med. $=2,91 \pm 0,109 \mathrm{~cm} \quad(\mathrm{C} . \mathrm{V} .=14,65 \%)$ and $\mathrm{P}$ med. $=0,33 \pm 0,017 \mathrm{~g}$ (C.V. $=20,98 \%)$. The age structure was not determined due to the preservation of intact bodily integrity (species without scales) and their alive returning to their living environment. Three specimens have been preserved for the laboratory collection.

The structure of catches and the contribution of each species to the formation of the fishing community is presented below. Thus, the caspian goby included into the category of subdominant species (D 3-2,4\%), accessories (C2-30\%), and attendant (W2-0,7\%).

As a result, after 50 years of uncertainty from the first registration, we can see not only a reappearance of the species on the territory of the Republic, but also an obvious expansion of it in the Lower Dniester Riverbed [11]. We can, repeatedly, confirm the tendencies of continuous modification of the fish fauna in the Republic of Moldova based on the finding of the presence of this species. As a result, the analysis of ichthyocenotic successions in the last 50 years shows a continuous increase in the share of representatives of the Gobiidae family in the country. 
Among the most essential causes, which led to the biological progression of ponto-caspian gobyes on the territory of the Republic, we can mention: 1) anthropogenic factors - fragmentation and regularization of lotic ecosystems with limnification effect, clogging, district heating and mineralization; unregulated fishing of natural predators and strong competitors 2) climatic factors- the trend of global warming and the intensification of natural cataclysms 3) of biocenotic order - spreading of lotic biotopes with macrophytes that serve as refuge areas for the representatives of this family, the proliferation of bivalve mollusks whose shells serve as reproductive substrate for spawning, the deficit of ichthyophagous species, the increase of available food resources 4) idioadaptive order - small body size, hidden benthic lifestyle, pronounced mimicry, care for offspring and high survival of offspring, early maturation $(0+, 1+)$, portioned reproduction, broad trophic spectrum - from malocophagy to optional ichthyophagy; they are eurythermic, mixohaline and eurioxybionte species; missing of larval stages [1].

\section{Conclusions}

Presence identification of this species confirms the conception regarding the biological progression of the Gobiidae family (Ponto-Caspian relics) in current ecological conditions.

The model way of spread and numerical dynamics of the species is similar to Black Sea tadpole-goby - Benthophilus nudus Berg, 1898, which also recently demonstrates an obvious biological progression in the Dniester and Prut Rivers.

The biological progression of the Ponto-Caspian relics of the Gobiidae family is a strong indicator of accentuated climate change. Thus, current global warming and the progression of some relict species can be correlated with the interglacial phases in climate change.

Acknowledgements: The investigations were carried out within the project no. 20.80009.7007.06 AQUABIO and international projects BSB165 HydroEcoNex and BSB 27 MONITOX funded by the EU Black Sea Joint Operational Programme 2014-2020. The content of this publication is sole responsiblity of the authors and does not reflect the views of the European Union.

\section{Bibliography}

1. Bulat, D. Ihtiofauna Republicii Moldova: geneza, starea actuală, tendințe și măsuri de ameliorare. Autoreferatul tezei de doctor habilitat în științe biologice. Chișinău, 2019. p. 68.

2. Cartea Roșie a Republicii Moldova. Ed. a 3-a. - Ch.: Î.E.P. Știința, 2015, 492 p.

3. Cozari, T., Usatîi, M., Vladimirov, M. Seria: Lumea animală a Moldovei. Pești. Amfibieni. Reptile. vol. II. Ed. „Ştiinţa”. Chişinău, 2003, 150 p.

4. Ghid pentru identificarea speciilor de pești ai Nistrului, incluși în Cartea Roșie a Republicii Moldova. Eco-Tiras. Chişinau 2020, p. 48-49

5. Gomoiu, M.-T., Skolka, M. Ecologie. Metodologii pentru studii ecologice. Ed. Ovidius University Press, Constanța, 2001, p. 173.

6. Kottelat M., Freyhof J. Handbook of European freshwater fishes. Berlin, 2007.

7. Peştii Nistrului de Mijloc şi de Jos (Ghid al păstrătorilor râului). / Moşu A., Trombiţki I. Chişinău, 2013.

8. Атлас пресноводных рыб России: В двух томах. Под ред. Решетникова Ю.С. 2002. М.: Наука. Т.2. $251 \mathrm{c.}$ 
9. Животный мир Молдавии. Рыбы. Земноводные. Пресмыкающиеся. Под ред. Ганя И. Изд. Штиинца, Кишинэу, 1981, с. 27-130

10. Васильева Е.Д. Популярный атлас-определитель. Рыбы. М.: Дрофа. 2004.

11. Владимиров М.3, Кубрак И.Ф. О нахождении нового для ихтиофауны бассейна Днестра вида бычков Caspiosoma caspium (Kessler). Вопросы ихтиологии. 1972, Т. 12, вып. 2, с. $386-387$.

12. Долгий, В.Н. Ихтиофауна Днестра и Прута (современное состояние, генезис, экология и биологические основы рыбохозяйственного использования). Изд. Штиинца. Кишинев, 1993,323 c.

13. Манило Л.Г. Бычковые рыбы (Gobiidae, Perciformes) северо-западной части Черного моря и прилегающих лиманных экосистем. Збірник праць Зоологічного музею. 20082009, Вып. 40, с. 19-46.

14. Манило Л.Г. К распространению некоторых видов семейства бычковых рыб (Perciformes, Gobiidae) в водах Украины. Vestnik zoologii, 2009, 43(3): 275-281

15. http://:www.fishbase.org/search.php

16. https://www.iucnredlist.org/species/135622/4164175

17. https://redbook-ua.org/ru/category/gobiidae/ 